\title{
POLA ASUH DENGAN KEJADIAN STUNTING PADA BALITA DI KABUPATEN POLEWALI MANDAR
}

\author{
Yudianti, Rahmat Haji Saeni \\ Jurusan Gizi Poltekkes Kemenkes Mamuju,
}

\begin{abstract}
Stunting is a condition which indicated by chronic growth inhibition and caused by long-term malnutrition. In Tinambung district has 50.9\% stunting cases. Stunting in children caused by several factors related among parenting. The objective of this study is to know association parenting consists of feeding practices, hygiene practices and seeking treatment practices in infants. This study was observational case control study with 51 stunting toddlers samples and 51 toddlers normal by systematic random sampling. The independent variables consist of feeding practices, hygiene practices and health seeking practices while the dependent variable is toddler who suffered stunting. Statistical analysis by bivariate with Chi Square test. There is association between feeding practices, personal hygiene practice with incidence of stunting toddlers. There is no association between seeking treatment practices with of stunting toddlers.
\end{abstract}

Keyword: stunting, toddlers, parenting

\section{PENDAHULUAN}

Stunting adalah suatu keadaan yang ditunjukkan dengan terhambatnya pertumbuhan yang bersifat kronis yang disebabkan oleh malnutrisi jangka panjang. Menurut WHO Child Growth Standart, stunting didasarkan pada indeks panjang badan dibanding umur $(\mathrm{PB} / \mathrm{U})$ atau tinggi badan dibanding umur (TB/U) dengan batas (z-score) kurang dari -2 SD (WHO, 2010). Stunting pada anak disebabkan oleh beberapa faktor yang saling berhubungan di antaranya adalah faktor gizi yang terdapat pada makanan. Kualitas dan kuantitas asupan gizi pada makanan anak perlu mendapat perhatian oleh karena sering rendah akan zat gizi yang dibutuhkan guna menunjang pertumbuhan. Hal ini menunjukkan bahwa untuk mendukung asupan gizi yang baik perlu ditunjang oleh kemampuan ibu dalan memberikan pengasuhan yang baik bagi anak dalam hal praktek pemberian makan, praktek kebersihan diri/ lingkungan maupun praktek pencarian pengobatan (Anugraheni HS, 2012). Indonesia masih harus bekerja keras mengatasi stunting karena batas yang ditetapkan WHO adalah prevalensi stunting rendah $<20 \%$, sedang $20-29 \%$ dan tinggi $\geq$ $30 \%$ (WHO, 2005). Kejadian stunting pada balita di Indonesia masih tinggi, yaitu 36,8\% pada tahun 2007 menjadi 37,2\% pada tahun 2013 sedangkan prevalensi untuk Propinsi Sulawesi Barat menunjukkan persentase diatas $40 \%$, dimana terjadi peningkatan dibanding hasil Riskesdas tahun 2010 (Depkes RI, 2013).
Kecamatan Tinambung merupakan salah satu dari 16 kecamatan yang berada di wilayah Kabupaten Polman Propinsi Sulawesi Barat. Hasil Pemantauan Status Gizi di wilayah Kecamatan Tinambung tahun 2014 menunjukkan dari 864 balita yang diukur status gizinya diperoleh sebanyak 440 balita yang mengalami stunting atau sebesar 50,9\% (Puskesmas Tinambung, 2014). Penelitian ini bertujuan untuk mengetahui hubungan pola asuh dengan kejadian stunting pada balita.

\section{METODE PENELITIAN Jenis Penelitian}

Penelitian ini adalah penelitian observasional dengan menggunakan rancangan penelitian case control yaitu mengidentifikasi subjek yang mengalami stunting (kelompok kasus) dan subjek yang tidak mengalami stunting (kelompok kontrol). Penelitian dilaksanakan di wilayah Kecamatan Tinambung dengan pertimbangan bahwa berdasarkan data Pemantauan Status Gizi balita, kecamatan ini memiliki persentase balita yang mengalami stunting sebesar 50,9\%. Penelitian dilaksanakan di wilayah Kecamatan Tinambung dan waktu pelaksanaan penelitian bulan Juli sampai Oktober tahun 2015.

\section{Populasi dan Sampel Penelitian}

Populasi penelitian ini adalah seluruh keluarga yang memiliki balita yang berada di wilayah Kecamatan Tinambung sebanyak 2422 anak. Sampel dalam penelitian ini adalah 
keluarga yang memiliki balita stunting berdasarkan pengukuran antropometri dengan indikator $\mathrm{TB} / \mathrm{U}$ (kasus) dan keluarga yang memiliki balita yang tidak stunting berdasarkan pengukuran antropometri dengan indikator TB/U (kontrol) dengan matching menurut jenis kelamin dan usia anak yang dikelompokkan berdasarkan kelompok umur. dari kelompok kasus dan kontrol. Adapun kriteria inklusi dan eksklusi sebagai berikut: anak diasuh oleh ibu, anak mengalami stunting, bersedia untuk ikut dalam penelitian, anak dalam keadaan sehat, keluarga yang memiliki lebih dari satu anak stunting, maka salah satu balitanya yang stunting (anak tertua) diambil sebagai sampel sedangkan pada kelompok kasus : anak diasuh oleh ibu, anak tidak mengalami stunting, bersedia untuk ikut dalam penelitian, anak dalam keadaan sehat, keluarga yang memiliki lebih dari satu anak stunting, maka salah satu balitanya yang stunting (anak tertua) diambil sebagai sampel

\section{Tekhnik Pengambilan Sampel}

Besar sampel untuk studi kasus kontrol tak berpasangan ditentukan dengan menggunakan rumus perhitungan besar sampel (Madiyono B. dkk, 2002). Diperoleh sebanyak 51 sampel dengan perbandingan kasus dan kontrol 1:1, sehingga jumlah kasus sebanyak 51 anak yang stunting dan sebagai kontrol berjumlah 51 anak yang tidak stunting. Teknik pengambilan sampel secara sistematic random sampling.

\section{Variabel Penelitian dan Cara Pengukuran}

Variabel independen adalah praktek pemberian makan, praktek kebersihan diri dan praktek pencarian pengobatan. Variabel ini diukur dengan menggunakan kuesioner melalui wawancara langsung kepada responden. Kuesioner karakteristik keluarga untuk mengetahui identitas sampel dan identitas orang tua, dikumpulkan pada waktu pengambilan data di puskesmas, yang diperoleh dari rekapan data sasaran anak balita di tingkat desa.yang terdiri dari beberapa pertanyaan yang diajukan pada responden. Variabel dependen adalah balita yang mengalami stunting. Variabel dependen diperoleh berdasarkan data hasil pengukuran panjang badan untuk anak umur $6-23$ bulan diukur dengan menggunakan alat pengukur panjang badan sedangkan data tinggi badan anak umur $24-59$ bulan diukur dengan microtoice ketelitian $0,1 \mathrm{~cm}$. Posisi anak tegak lurus dengan pandangan ke depan, kaki rapat ke tembok dan tidak menggunakan penutup kepala maupun alas kaki. Kegiatan pengukuran ini dibantu oleh enumerator.

\section{Pengolahan Data}

Data yang telah dikumpulkan diedit, diolah kemudian dilakukan analisis data meliputi: Analisis Univariat yaitu analisis yang dilakukan untuk menjelaskan karakteristik masing-masing variabel yang diteliti, Bivariat yaitu analisis untuk mengetahui hubungan antara variabelvariabel bebas dan variabel terikat dimana dilakukan analisis statistik dengan menggunakan uji chi square $\left(\mathrm{x}^{2}\right)$ untuk menganalisis variabel yang berskala kategorikkategorik sedangkan untuk mengetahui keeratan hubungan antara variabel digunakan ukuran Odds Ratio (OR).

\section{HASIL}

\section{Gambaran Wilayah Kecamatan Tinambung}

Kecamatan Tinambung adalah salah satu dari 16 kecamatan yang berada di wilayah Kabupaten Polman Propinsi Sulawesi Barat dengan batas wilayah kerja $21,7 \mathrm{~km}^{2}$, yang terdiri dari 1 kelurahan dan 7 desa yaitu Kelurahan Tinambung, Desa Batulaya, Sepabatu,Tangnga-tangnga, Galung lombok, Lekopadis, Karama dan Tandung.

\section{Karakteristik Subjek Penelitian}

Pada penelitian ini distribusi jumlah anggota keluarga pada kelompok kasus dan kontrol sama sedangkan status pekerjaan ibu, persentase terbesar adalah ibu tidak bekerja pada kelompok kasus. Distribusi balita menurut jenis kelamin antara kasus dan kontrol adalah sama dimana persentase laki-laki sebanyak 26 orang dan perempuan 25 orang. Adapun distribusi sampel berdasarkan penggolongan umur, persentase terbesar pada kelompok umur $12-23$ bulan. Distribusi karakteristik subjek penelitian dapat dilihat pada Tabel 1.

\section{Pola Asuh dengan Kejadian Stunting pada Balita}

Pada Tabel 2 dapat dilihat variabel pola asuh yang terdiri dari praktek pemberian makan, praktek kebersihan diri dan praktek pencarian pengobatan antara ibu yang mengalami stunting dan tidak stunting. Praktek ibu yang kurang baik banyak terdapat pada balita yang stunting. Hasil analisis praktek pemberian makan diperoleh sebanyak $32 \quad(62,7 \%) \quad$ ibu 
menunjukkan praktek perawatan yang kurang baik pada kelompok kasus dan pada ibu yang memberikan praktek pemberian makan terhadap balita baik diperoleh sebanyak 30 $(58,8 \%)$ pada kelompok kontrol. Ada hubungan antara praktek pemberian makan dengan kejadian stunting yang ditunjukkan dengan nilai $p=0,02$ dan $\mathrm{OR}=2,4$ yang berarti praktek pemberian makan yang kurang baik memiliki risiko 2,4 kali lebih tinggi untuk mengalami stunting dibandingkan dengan praktek pemberian yang baik.

Tabel 1. Distribusi Karakteristik Subjek Penelitian

\begin{tabular}{|c|c|c|c|c|c|c|}
\hline \multirow{3}{*}{ Karakteristik } & \multicolumn{4}{|c|}{ Sampel } & \multirow{2}{*}{\multicolumn{2}{|c|}{ Total }} \\
\hline & \multicolumn{2}{|c|}{ Kasus } & \multicolumn{2}{|c|}{ Kontrol } & & \\
\hline & $\mathbf{n}$ & $\%$ & $\mathbf{n}$ & $\%$ & $\mathbf{N}$ & $\%$ \\
\hline \multicolumn{7}{|c|}{ Jumlah Anggota Keluarga } \\
\hline$\leq 4$ orang & 28 & 54,9 & 23 & 45,1 & 51 & 50,0 \\
\hline$>4$ orang & 23 & 45,1 & 28 & 54,9 & 51 & 50,0 \\
\hline \multicolumn{7}{|l|}{ Pekerjaan Ibu } \\
\hline Bekerja & 10 & 19,6 & 15 & 29,4 & 25 & 24,5 \\
\hline Tidak Berkerja & 41 & 80,4 & 36 & 70,6 & 77 & 75,5 \\
\hline \multicolumn{7}{|l|}{ Umur Balita (tahun) } \\
\hline $6-11$ & 4 & 7,8 & 4 & 7,8 & 8 & 7,8 \\
\hline $12-23$ & 13 & 25,5 & 13 & 25,5 & 26 & 25,0 \\
\hline $24-35$ & 12 & 23,5 & 12 & 23,5 & 24 & 23,5 \\
\hline $36-47$ & 12 & 23,5 & 12 & 23,5 & 24 & 23,5 \\
\hline $48-59$ & 10 & 19,7 & 10 & 19,7 & 20 & 19,6 \\
\hline \multicolumn{7}{|l|}{ Jenis Kelamin } \\
\hline Laki - laki & 26 & 51 & 26 & 51 & 52 & 51,0 \\
\hline Perempuan & 25 & 49 & 25 & 49 & 50 & 49,0 \\
\hline
\end{tabular}

Hasil analisis praktek kebersihan diri diperoleh sebanyak $16 \quad(31,4 \%)$ ibu menunjukkan praktek yang kurang baik pada kelompok kasus dan pada ibu yang memberikan praktek kebersihan diri terhadap balita baik diperoleh sebanyak 45 ( $88 \%$ ) pada kelompok kontrol. Ada hubungan antara praktek kebersihan diri dengan kejadian stunting yang ditunjukkan dengan nilai $p=0,016$ dan $\mathrm{OR}=$ 3,42 yang berarti praktek kebersihan diri yang kurang baik memiliki risiko 3,42 kali lebih tinggi untuk mengalami stunting dibandingkan dengan praktek kebersihan diri yang baik.

Hasil analisis praktek pencarian pengobatan diperoleh sebanyak $11(21,6 \%)$ ibu menunjukkan praktek yang kurang baik pada kelompok kasus dan pada ibu yang memberikan praktek kebersihan diri terhadap balita baik diperoleh sebanyak $36(68,6 \%)$ pada kelompok kontrol. Tidak ada hubungan antara praktek pencarian pengobatan dengan kejadian stunting yang ditunjukkan dengan nilai $p=0,36$ dan OR $=0,6$. Hasil uji hubungan pola asuh dengan kejadian stunting dapat dilihat pada Tabel 2.

\section{PEMBAHASAN}

Gangguan pertumbuhan pada balita sudah mulai muncul pada usia dini. Stunting merupakan gangguan pertumbuhan yang terjadi pada balita. Kondisi stunting perlu mendapat perhatian khusus karena dapat menghambat perkembangan fisik dan mental anak. Stunting berkaitan juga dengan peningkatan risiko kesakitan dan kematian serta terhambatnya pertumbuhan kemampuan motorik dan mental. Salah satu faktor tidak langsung yang berpengaruh dengan kejadian stunting adalah pola asuh.

Hasil penelitian menunjukkan bahwa praktek pemberian makan berhubungan dengan kejadian stunting pada balita yang ditunjukkan pada Tabel 2 artinya praktek pemberian makan yang kurang baik yang diberikan pada anak akan memberikan peluang untuk terjadinya stunting. Hasil penelitian ini juga sesuai dengan penelitian (Amin AM, 2003) bahwa ada hubungan yang bermakna antara pola asuh dengan status gizi anak usia $6-24$ bulan dimana pola asuh makan yang baik berdampak 
pada status gizi anak normal. Praktek pemberian makan pada anak sangat penting dan besar pengaruhnya bagi pertumbuhan anak. Memberikan suasana yang nyaman bagi anak pada saat makan, mengetahui selera makan yang baik pada anak, sabar dan penuh perhatian pada saat memberikan makan tentu dapat menjalin keakraban di antara keduanya sehingga diharapkan anak mampu menghabiskan makanan yang diberikan. Hasil penelitian di pesisir Kota Makassar menunjukkan praktek pemberian makan berhubungan dengan kejadian stunting
(Renyoet SB, 2012). Hal ini berbeda dengan penelitian di pedalaman Kalimantan yang menunjukkan bahwa tida ada hubungan antara pola makan dengan kejadian stunting (Wahdah S, 2012). Banyak faktor yang mendukung terjadinya stunting pada anak. Kualitas asupan zat gizi serta paparan terhadap infeksi merupakan faktor utama penyebab gangguan pertumbuhan pada balita. Menyusui, memberi makan dengan cara makan yang sehat, memberi makan bergizi dan mengontrol besar porsi yang dihabiskan akan meningkatkan status gizi anak (Sawadogo, et al, 2015).

Tabel 2. Uji Hubungan Pola Asuh dengan Kejadian Stunting pada Balita

\begin{tabular}{|c|c|c|c|c|c|c|c|c|c|}
\hline \multirow{3}{*}{ Pola Asuh } & \multicolumn{4}{|c|}{ Sampel } & \multirow{2}{*}{\multicolumn{2}{|c|}{ Total }} & \multirow{3}{*}{$P^{a}$} & \multirow{3}{*}{ OR } & \multirow{3}{*}{ CI } \\
\hline & \multicolumn{2}{|c|}{ Kasus } & \multicolumn{2}{|c|}{ Kontrol } & & & & & \\
\hline & $\mathbf{n}$ & $\%$ & $\mathbf{n}$ & $\%$ & $\mathbf{n}$ & $\%$ & & & \\
\hline \multicolumn{10}{|l|}{ Praktek Pemberian } \\
\hline Makan & & & 30 & & & & \multirow{3}{*}{$0,02^{*}$} & \multirow{3}{*}{2,4} & \multirow{3}{*}{$1,086-5,33$} \\
\hline Baik & 32 & 62.7 & 21 & 41,2 & 53 & 52 & & & \\
\hline Kurang baik & & & & & & & & & \\
\hline \multicolumn{10}{|c|}{ Praktek Kebersihan Diri } \\
\hline Baik & 35 & 68,6 & 45 & 88 & 88 & 78,4 & \multirow{2}{*}{$0,016^{*}$} & \multirow{2}{*}{3,42} & \multirow{2}{*}{$1,215-9,67$} \\
\hline Kurang baik & 16 & 31,4 & 6 & 12 & 22 & 21,6 & & & \\
\hline \multicolumn{10}{|l|}{ Praktek Pencarian } \\
\hline \multicolumn{10}{|l|}{ Pengobatan } \\
\hline Baik & 40 & 78,4 & 36 & 68,6 & 78 & 74,5 & \multirow{2}{*}{0,36} & \multirow{2}{*}{0,6} & \multirow{2}{*}{$0,26-1,62$} \\
\hline Kurang baik & 11 & 21,6 & 15 & 31,4 & 26 & 25,5 & & & \\
\hline
\end{tabular}

${ }^{a}$ Chi Square

${ }^{*}<<0,05$

Hasil penelitian menunjukkan adanya hubungan antara praktek kebersihan diri dengan balita stunting artinya praktek kebersihan diri yang kurang baik oleh ibu memberikan risiko kejadian stunting pada balita. Hal ini sejalan dengan penelitian di pesisir yang menunjukkan bahwa ada hubungan antara praktek kebersihan diri dengan kejadian stunting pada balita (Renyoet SB, 2012). Data Water Sanitation Program melaporkan bahwa adanya kelangkaan air bersih dan sanitasi berdampak pada tingginya angka kematian bayi dan balita (Bappenas, 2012).

Hasil penelitian menunjukkan bahwa praktek pencarian pengobatan tidak berhubungan dengan stunting pada balita. Hal ini terjadi karena akses masyarakat terhadap pelayanan kesehatan sangat mudah diperoleh karena jarak yang dekat antara desa dengan ibukota kecamatan, adanya sarana transportasi yang lancar, adanya petugas kesehatan yang bertanggungjawab di desa sebagian besar menetap di desa binaan tersebut dan adanya pelayanan BPJS menyebabkan para petugas meningkatkan pelayanan kesehatan sampai kepelosok. Berbeda dengan hasil penelitian di daerah pesisir Kota Makassar yang menyatakan bahwa bila anak sakit maka para ibu tidak langsung mengunjungi pusat pelayanan kesehatan sehingga kondisi kesehatan anaknya bisa semakin parah pada saat dibawa ke pelayanan kesehatan. Begitupun dengan penelitian lainnya yang menyatakan bahwa tidak terjangkaunya pelayanan kesehatan disebabkan oleh masyarakat tidak mampu membayar, jauh dari sarana pelayanan, pendidikan dan pengetahuan ibu yang rendah merupakan kendala masyarakat dalam memanfaatkan secara baik pelayanan kesehatan yang tersedia sehingga berdampak pada status gizi (Ayu DS, 2008). 


\section{KESIMPULAN}

Ada hubungan antara praktek pemberian makan dan kebersihan diri dengan kejadian stunting pada balita. Tidak ada hubungan antara praktek pencarian pengobatan dengan kejadian stunting pada balita.

\section{DAFTAR PUSTAKA}

WHO. (2010). Nutrition landscape information system (NLIS) country profile indicators.

Anugraheni HS. (2012). Faktor risiko kejadian tunting pada anak usia 12 36 Bulan di Kecamatan Pati, Kabupaten Pati. Program Studi Ilmu Gizi Fakultas Kedokteran Universitas Diponegoro. Semarang.

WHO. (2005). Global database on child and malnutrition.

Depkes RI (2013). Laporan Hasil Riset Kesehatan Dasar Indonesia. Jakarta.

Puskesmas Tinambung (2015). Laporan PSG Puskesmas Tinambung Tahun 2014.

Amin AM. (2003). Hubungan pola asuh dan asupan gizi terhadap status gizi anak usia 6-24 Bulan pada daerah Pesisir Pantai di Kelurahan Mangempang Kecamatan Barru Kabupaten Barru. Tesis. Yogyakarta: Universitas Gadjah Mada.

Renyoet SB. (2012). Hubungan Pola Asuh dengan Kejadian Stunting Anak Usia 6 -
23 Bulan di Wilayah Pesisir Kecamatan Tallo Kota Makassar. Jurnal repository. Unhas.ac.id.

Wahdah S. (2012). Faktor Risiko Kejadian Stunting pada Anak Umur 6 - 36 Bulan di Pedalaman Kecamatan Silat Hulu Kabupaten Kapuas Hulu Provinsi Kalimantan Barat. Online public acces catalog. Electronic thesis and dissertations gadjah mada university, http://etd.repository.ugm.ac.id.

Sawadogo, et al. (2010). An Infant and Child Feeding Index Is Associated with the Nutritional Status of $6-23$ to month old Children in Rural Burkina Faso. Community and International Nutrition, http://www.unicef.org/eapro/Workshop [diakses 12 januari 2015].

Bappenas. (2012). Kerangka Kebijakan Gerakan Sadar Gizi dalam Rangka Seribu Hari Pertama Kehidupan (1000 HPK). [online]. Jakarta: Badan Perencanaan Pembangunan Nasional.

Ayu DS. (2008). Pengaruh Program Pendampingan Gizi terhadap Pola Asuh, Kejadian Infeksi dan Status Gizi Balita Kurang Energi Protein. Tesis magister gizi masyarakat. Program pascasarjana. Universitas Diponegoro. Semarang. 